\title{
Effectiveness of Health Education With Media Leaflet on Knowledge and Attitude of Self-Breast Examination in Young Woman
}

\author{
$1^{\text {st Jajuk Kusumawaty }}$ \\ STIKes Muhammadiyah Ciamis \\ Jln KH.Ahmad Dahlan No.20 \\ Ciamis, Indonesia \\ jajuk09@yahoo.com \\ $4^{\text {th }}$ Heni Heryani \\ STIKes Muhammadiyah Ciamis \\ Jln KH.Ahmad Dahlan No.20 \\ Ciamis, Indonesia
}

\author{
$2^{\text {nd }}$ Asep Gunawan \\ STIKes Muhammadiyah Ciamis \\ Jln KH.Ahmad Dahlan No.20 \\ Ciamis, Indonesia \\ $5^{\text {th }}$ Lilis Lismayanti \\ STIKes Muhammadiyah Ciamis \\ Jln KH.Ahmad Dahlan No.20 \\ Ciamis, Indonesia
}

\author{
$3^{\text {rd }}$ Dedi Supriadi \\ STIKes Muhammadiyah Ciamis \\ Jln KH.Ahmad Dahlan No.20 \\ Ciamis, Indonesia \\ $6^{\text {th }}$ Dede Samrotul Milah \\ STIKes Muhammadiyah Ciamis \\ Jln KH.Ahmad Dahlan No.20 \\ Ciamis, Indonesia
}

\begin{abstract}
Breast self-examination is an activity carried out by a woman to detect abnormalities in the breast. Breast self-examination activities should be done once every month, for women who still experience regular menstruation, it is advisable to do breast self-examination on the 7th day to the 10th day of menstruation is calculated from the first day of menstruation. Health education using audiovisuals or lectures has often been done, whereas individual counseling in the form of leaflets is rarely done so this research needs to be done. The purpose of this study was to determine the Effectiveness of Health Education with Media Leaflets on Knowledge and Attitudes of Breast Self-Examination (BSE) in young women. The method used was pre-experimental with one group pretest-posttest design. The sampling technique used incidental sampling of 76 respondents. Bivariate analysis techniques using Wilcoxon. Wilcoxon's statistical test results produce a significance value of $p$-value between the effectiveness of health education with media leaflets on BSE knowledge of 0,000 with p-value $0,000<0.05$ and BSE attitude of 0,000 with a p-value of $0,000<0.05$. The conclusion is that there are statistically and clinically significant differences between BSE knowledge and attitudes before and after health education with media leaflets.
\end{abstract}

Keywords-Health Education, Leaflet, Knowledge, Attitude

\section{INTRODUCTION}

\section{A. Background}

Breast cancer is a malignancy that occurs in the sac and or milk-producing ducts. The level of danger of malignancy and breast cancer is the same. It's just that, the number of breast cancer sufferers is more (about 90\%) compared to sufferers of breast malignancy[1]. Based on data Globocan International Agency for Research on Cancer (IARC), a cancer research institute from WHO in 2013, it is known that breast cancer is cancer with the highest percentage of new cases. The number of breast cancer sufferers has increased by 1.7 million women from the previous 6.3 million who have been diagnosed with breast cancer in the past 5 years. Breast cancer is also the most common cause of death in women, amounting to 522,000 deaths[2].

National Health Research in 2013 nationally, the prevalence of cancer in all ages in Indonesia in 2013 was
$1.4 \%$ or around 61,682 with a percentage of breast cancer of $0.5 \%$ [3]. Data from the province of West Java in 2013 breast cancer was cancer with the highest prevalence in Indonesia in 2013, as many as 6,701 cases of breast cancer[4].

Data collected from the Indonesian Cancer Foundation of Ciamis District for cancer patients reached around 70 people. As many as 30 people affected by breast cancer, 5 people with cervical cancer, while the remaining various types of cancers ranging from skin cancer, brain tumors, eyes, and others. In 2018, breast cancer sufferers will increase by 38 people. Based on a report from the Indonesian Cancer Foundation (YKI) Ciamis who is not affected by breast cancer is not just the elderly or the elderly, but many teenagers have breast cancer. Therefore it is necessary to hold early detection of breast cancer from the age of adolescence[5].

One factor in the high incidence is the lack of breast cancer education since adolescents in detecting and treating breast cancer early[6]. Sufficient knowledge of the benefits of a thing will cause someone to have a positive attitude towards it. Attitude is a reaction or response that is still closed from someone to an object. A positive attitude towards an object will affect a person in acting and participating in an action such as the practice of breast self-examination (BSE). But it is this lack of knowledge that causes many adolescents in Indonesia who ultimately do not have a positive attitude toward breast self-examination (BSE)[7].

Results of a preliminary study conducted at the ArRisalah Islamic boarding school in the Ciamis Regency on January 4, 2019, obtained information from the boarding school management that at the Islamic boarding school had never received health education especially about breast cancer education and breast self-examination from local health personnel. Researchers chose to research in pesantren, namely the lack of information about health because researchers felt learning in pesantren was only religious. The results of interviews about BSE conducted randomly to 8 female students found that 1 student learned about BSE and obtained information about BSE from the article and did not practice it and 7 people said they did 
not know about BSE at all. Based on the description above, researchers are interested in researching "The Effectiveness of Using Media Leaflets on Knowledge and Attitudes About Self Breast Examination (BSE) in Young Women".

\section{METHOD}

\section{A. Research Design}

The type of research used is a type research Preexperimental with the research design used is Pretest and Posttest One Group Design.

\section{B. Research Location and Time}

This research was conducted at Pondok Ar Boarding School on May 2, 2019.

\section{Population}

The population in this study were young woman in grades 8, 9 and high school grades 10,11, 12 at Ar Risalah Islamic Boarding School totaling 223 people. Grade 7 was not taken because it was feared that someone had not yet menstruated.

D. Samples

The type of sample used in this study is the incidental sampling technique. The sample size is determined with a precision set at $10 \%$ with a confidence level of $95 \%$. So that the sample of this study was 76 people.

\section{RESULTS AND DISCUSSION}

A. Research Results

1) Univariate Analysis

TABLE 1 , FREQUENCY DISTRIBUTION OF KNOWLEDGE LEVELS ABOUT BSE

\begin{tabular}{|c|c|c|c|c|c|}
\hline \multirow{2}{*}{ No } & \multirow{2}{*}{$\begin{array}{c}\text { Knowl } \\
\text { edge }\end{array}$} & & \multicolumn{2}{|c|}{ Pretest } & \multicolumn{2}{c|}{ Posttest } \\
\cline { 3 - 6 } & & Frequency & Percentage & Frequency & Percentage \\
\hline 1 & Good & 18 & 23.7 & 70 & 92.1 \\
\hline 2 & $\begin{array}{c}\text { Suffici } \\
\text { ent }\end{array}$ & 27 & 35.5 & 6 & 7.9 \\
\hline 3 & Less & 31 & 40.8 & 0 & 0 \\
\hline & & 76 & 100 & 76 & 100 \\
\hline
\end{tabular}

The results of the analysis in table 1 . above can find out the level of knowledge of young women in the Ar-Risalah boarding school before being given health education with the media leaflet most number of categories, namely 31 people $(40.8 \%)$. After being given health education with the media leaflets most good categories of, 70 people $(92.1 \%)$.

TABLE 2. FREQUENCY DISTRIBUTION OF ATTITUDES LEVELS ABOUT BSE

\begin{tabular}{|c|l|c|c|c|c|}
\hline \multirow{2}{*}{ No } & \multirow{2}{*}{ Attitudes } & $\begin{array}{c}|c| \\
\text { Frequenc } \\
\mathrm{y}\end{array}$ & Percentage & $\begin{array}{c}\text { Freq } \\
\text { uenc } \\
\mathrm{y}\end{array}$ & $\begin{array}{c}\text { Perce } \\
\text { ntage }\end{array}$ \\
\cline { 3 - 6 } & & & & \\
\hline 1 & $\begin{array}{l}\text { Doesn't } \\
\text { Support }\end{array}$ & 8 & 10.5 & 0 & 0 \\
\hline 2 & Less Support & 37 & 48.7 & 0 & 0 \\
\hline 3 & Support & 29 & 38.2 & 6 & 7.9 \\
\hline 4 & $\begin{array}{l}\text { Strongly } \\
\text { Support }\end{array}$ & 2 & 2.6 & 70 & 92.1 \\
\hline & & 76 & 100 & 76 & 100 \\
\hline
\end{tabular}

The results of the analysis in table 2 . above can be seen in the attitudes of young women in the Ar Risalah boarding school before and after being given health education with a media leaflet. Before the given health education media leaflets most unfavorable category which strongly supports 37 many categories of 70 persons $(48.7 \%)$. After being given education people $(92.1 \%)$ health with the media leaflets most.

\section{2) Bivariate Analysis}

Data analysis in this study was processed using the Wilcoxon Signed Rank Test uses a significance level of $\alpha$ $=0.05$. This test examines variables before and after counseling. The results of the test analysis Wilcoxon can be seen in Table 3 .

TABLE 3 TEST RESULTS OF THE EFFECTS OF HEALTH EDUCATION WITH MEDIA LEAFLET ON KNOWLEDGE AND ATTITUDES IN YOUNG WOMEN AT AR RISALAH ISLAMIC BOARDING SCHOOL

\begin{tabular}{|l|c|c|}
\hline & Knowledge & Attitude \\
\hline$Z$ & $-6,653^{\mathrm{a}}$ & $-7,610^{\mathrm{b}}$ \\
\hline $\begin{array}{l}\text { Asymp. Sig. (2- } \\
\text { tailed) }\end{array}$ & .000 & .000 \\
\hline
\end{tabular}

Different test results (Wilcoxon) data pretest and posttest knowledge about the examination own breast (BSE) before and after health education with media leaflet with a p-value of $0,000(p<0.05)$ which means there is an influence of health education with media leaflet on knowledge about breast self-examination (BSE) in young women in Ar Risalah. In testing the data pretest and posttest attitudes about breast self-examination (BSE) before and after health education with the media leaflet with a p-value of $0,000(\mathrm{p}<0.05)$ which means there is an influence of health education with media leaflets on attitudes about breast self-examination (BSE) in young women at the Ar Risalah Islamic Boarding School.

\section{B. Differences Knowledge about Breast Self- Examination (BSE)}

The results showed there was an influence of health education using media leaflets on the knowledge of BSE. There is an increase in the mean knowledge after the intervention compared to before the intervention. The increase in the mean value of this knowledge was marked by an increase in respondents' knowledge of breast cancer, signs, and symptoms of breast cancer, and risk factors for breast cancer. The mean value of respondents' knowledge increased regarding BSE about the time of BSE and the implementation of BSE. After being given an intervention the results of the research categorized as good knowledge amounted to $92.1 \%$ amounting to 70 respondents and the category of knowledge lacking at $7.9 \%$ amounted to 6 respondents.

Some factors that influence one's knowledge according to are education, age, interest and creativity, experience, the culture of the surrounding environment, information, and motivation[8]. The results of interviews with the Board of Santri Management Boarding School in Ar Risalah have never been held health education about BSE examination so that, it has an impact on the level of knowledge of adolescents about BSE examination. If researchers observe from interviews with 8 young women in the Ar Risalah Islamic Boarding School, 7 people have never received health education about $\mathrm{BSE}$, so that the knowledge of adolescents is still low. This is because the 
environment around adolescents still lacks health education about breast self-examination. Sources of information also affect the knowledge of a teenager. Knowledge can be increased or increased with the information by using various types of media, namely print, and electronic media. The print media include posters, leaflets, brochures, magazines, newspapers, stickers, and pamphlets, while electronic media such as television, radio, and tape recorder, VCD, video.

The advantages of Leaflets according to are: durable, covers a lot of people, costs are not high, does not need electricity, can be taken anywhere, can reveal a sense of beauty, simplify understanding and increase learning enthusiasm. Weaknesses are: this media cannot stimulate sound effects and motion effects, easily folded[8].

According to the assumption that leaflet media researchers have some disadvantages when compared to video media, one of them is that the leaflet media only contains images while the video contains moving images. This difference can provide different information for some people, especially in the section on exposure to early detection steps or BSE. In the pictures in the leaflet, only steps are shown with guidelines in the form of images that are sometimes difficult for the audience to understand. But this becomes easy to understand if using video media because in the video is exemplified directly so that the audience immediately understands.

Research is done by providing education related to when women should do breast self-exam, anyone who is obliged to do breast self-exam and how to practice breast self-exam. The results of research at the Boarding School Ar Risalah for lack of knowledge of young women by $40.8 \%$ so it needs to be improved by providing health education media leaflets about BSE.

\section{Differences Attitude About Self Breast Examination (BSE)}

The results of this study indicate that there is an effect of health education using media leaflets on the knowledge of BSE. The results of the study before being given the highest intervention were the less supportive categories amounting to $48.7 \%$ totaling 37 respondents, but the very supportive category only gained $2.6 \%$ totaling 2 people.

Attitude is a response that is still closed from someone to a stimulus. One social psychologist, Newcomb stated that attitude is a willingness to act, and not an implementation of certain motives[8]. Attitudes can be formed from the social interactions experienced by individuals. This social interaction is more than just social contact and relationships between individuals as members of social groups, but in social interactions there is a reciprocal relationship that also influences the pattern of behavior of each individual as a member of the community, furthermore this social interaction can include relationships between individuals with the environment in determining this whole attitude, knowledge, thoughts, beliefs, and emotions play an important role[9].

Health education with the media leaflet is very influential on attitudes adolescent girls to improve the attitude of BSE of respondents, there is an increase in the results of the attitude after being given an intervention. Health education has a significant relationship with respondents' attitudes about BSE because health education about BSE is very important for respondents because it is expected that the provision of health education about BSE will increase knowledge and also the ability to do BSE to prevent breast cancer. With the knowledge and ability to do BSE indirectly will affect the attitude of respondents about the BSE.

This study is in line with research by Sari \& Utami (2017) that there is a significant influence between breast cancer counseling on attitudes about breast selfexamination in young women at the Al Munawir Krapyak Islamic Boarding School in Bantul. It is expected that young women can apply knowledge about breast selfexamination (BSE) routinely so that they can detect breast cancer early[10].

Characteristics of respondents based on sources of information about breast cancer during the pretest, most respondents never got information about breast cancer and how to examine it. According to [8], one component of attitude change is emotional life or evaluation of an object, which subsequently enters the level of attitude, accepting to mean that people want and pay attention to the stimulus provided.

\section{CONCLUSION}

There are differences in the knowledge and attitudes of young women about BSE before and after being given health education with the media leaflet.

\section{REFERENCES}

[1] P. M. Soemitro, Blak-blakan Kanker Payudara. Bandung: Mizan Pustaka, 2012

[2] D. P. Lestari, P. N. Prabamurti, and B. T. Husodo, "PENGARUH PENYULUHAN KESEHATAN TERHADAP PENGETAHUAN, SIKAP DAN PRAKTIK PERIKSA PAYUDARA SENDIRI (SADARI) SANTRI PUTRI PONDOK PESANTREN DAWAR KABUPATEN BOYOLALI," vol. 4, pp. 291-298, 2016

[3] N. Widaningrum, Pengaruh Pendidikan Kesehatan Tentang Kanker Payudara Terhadap Sikap Melakukan Sadari Siswi SMAN 1 Turi Sleman Yogyakarta.

[4] Kementrian Kesehatan RI, "InfoDatin Bulan Peduli Kanker Payudara," Jakarta Selatan, 2016.

[5] YKI, "Yayasan Kanker Indonesia Kabupaten Ciamis," 2017.

[6] F. Pontoh et al., "HUBUNGAN ANTARA PENGETAHUAN, SIKAP SERTA DUKUNGAN KELUARGA DENGAN TINDAKAN PEMERIKSAAN PAYUDARA SENDIRI ( SADARI ) PADA MAHASISWI SEMESTER II AKBID MAKARIWO HALMAHERA," no. April, 2017.

[7] D. H. Novasari, D. Nugroho, and S. Winarni, "Hubungan Pengetahuan, Sikap Dan Paparan Media Informasi Dengan Praktik Pemeriksaan Payudara Sendiri (Sadari) Pada Santriwati Pondok Pesantren Al Ishlah Tembalang Semarang Tahun 2016," vol. 4, 2016

[8] S. Notoatmodjo, Pendidikan dan Perilaku Kesehatan. Jakarta: Rineka Cipta, 2010.

[9] Azwar, Sikap Manusia, Teori dan Pengukurannya. Yogyakarta: Pustaka Pelajar, 2013

[10] I. Sari, W. C., \& Utami, "Pengaruh Penyuluhan Kanker Payudara Terhadap Sikap Sadari Pada Remaja Putri Di Pondok Pesantren Al Munawwir Krapyak Bantul Yogyakarta.," 2017. 